\title{
GAMBARAN KUALITAS TIDUR KELUHAN MUSKULOSKELETAL DAN HUBUNGANNYA PADA STAF AKADEMIK TAHUN 2020
}

\author{
Azzahra Brenda Tam ${ }^{1}$, Aulia Chairani ${ }^{2}$, Nurfitri Bustamam ${ }^{3}$ \\ Universitas Pembangunan Nasional Veteran Jakarta. \\ azzahrabrendat@upnvj.ac.id ${ }^{1}$, auliachairani@upnvj.ac.id ${ }^{2}$
}

\begin{abstract}
Musculoskeletal disorders (MSDs) are a global problem. In Indonesia, the prevalence of MSDs that disrupts activities reaches $9.2 \%$ in office workers with complaints of the neck by 68\%, upper back $62 \%$, and lower back $60 \%$. In developing countries, MSDs are the most common occupational diseases found in 40-95\% of lecturers. In 2020, the COVID-19 pandemic in Indonesia resulted in the government implementing work from home (WFH) which caused $66.3 \%$ of workers to experience musculoskeletal pain. This can be caused by not fulfilling sleep which is a physiological need. It was found that $41.9 \%$ of adults experienced sleep disturbances which affected the emergence of MSDs complaints. This study aimed to determine the relationship between sleep quality and musculoskeletal complaints. This is an analytical study using a cross-sectional design towards the lecturers and educational staff at the Faculty of Medicine Universitas Pembangunan Nasional Veteran Jakarta. A sample size of 84 people was taken using the purposive sampling technique. Data were collected online using the PSQI for sleep quality and NMQ for musculoskeletal. The data were analyzed using SPSS software. The results showed that the majority of respondents were female (54.8\%), had poor sleep quality (94\%), and experienced musculoskeletal complaints (73.8\%). The results of the Fisher test showed a significant relationship between sleep quality and musculoskeletal complaints ( $p=$ 0.016; OR = 13.5). The low quality of sleep in lecturers and educational staff increase the risk of developing musculoskeletal disorders.
\end{abstract}

Keywords : Lecturers, Musculoskeletal Complaints, Musculoskeletal Disorders (MSDs), Sleep Quality, Education Staff

\begin{abstract}
ABSTRAK
Musculoskeletal disorders (MSDs) merupakan masalah global. Di Indonesia, prevalensi MSDs yang menyebabkan terganggunya aktivitas mencapai 9,2\% pada pekerja kantoran dengan keluhan pada leher sebesar $68 \%$, punggung atas $62 \%$, dan punggug bawah $60 \%$. Di negara berkembang, MSDs merupakan penyakit akibat kerja yang paling sering ditemukan pada 40-95\% staf pengajar. Pada tahun 2020, pandemi COVID-19 di Indonesia mengakibatkan pemerintah menerapkan work from home (WFH) yang menyebabkan $66,3 \%$ pekerja mengalami nyeri muskuloskeletal. Hal ini dapat disebabkan oleh tidak terpenuhinya tidur yang merupakan kebutuhan fisiologis. Didapatkan sebanyak $41,9 \%$ orang dewasa mengalami gangguan tidur yang berefek pada munculnya keluhan MSDs. Tujuan penelitian ini adalah mengetahui hubungan kualitas tidur dengan keluhan musculoskeletal. Penelitian ini merupakan penelitian analitik menggunakan desain cross sectional pada dosen dan tenaga kependidikan Fakultas Kedokteran Universitas Pembangunan Nasional Veteran Jakarta. Besar sampel sebanyak 84 orang diambil dengan teknik purposive sampling. Pengambilan data secara daring menggunakan kuesioner PSQI untuk kualitas tidur dan NMQ untuk keluhan muskuloskeletal. Data dianalisis menggunakan software SPSS. Hasil penelitian menunjukkan mayoritas responden berjenis kelamin perempuan $(54,8 \%)$, memiliki kualitas tidur yang buruk $(94 \%)$, dan mengalami keluhan muskuloskeletal $(73,8 \%)$. Hasil uji Chi-square menunjukkan terdapat hubungan yang signifikan antara kualitas tidur dengan keluhan muskuloskeletal ( $\mathrm{p}=0,016$; OR $=13,5)$. Rendahnya kualitas tidur pada profesi dosen dan tenaga kependidikan meningkatkan risiko timbulnya gangguan muskuloskeletal.
\end{abstract}

Kata Kunci : Dosen, Keluhan Muskuloskeletal, Kualitas Tidur, Musculoskeletal Disorders (MSDs), Tenaga Kependidikan 


\section{PENDAHULUAN}

Pada saat ini keluhan muskuloskeletal merupakan masalah global. Di negara berkembang, musculoskeletal disorders merupakan penyakit akibat kerja yang paling sering ditemui pada $40-95 \%$ staf mengajar. Hal ini dikarenakan berbagai aktivitas mengajar, menyiapkan materi, dan mengerjakan administrasi lainnya berdampak pada kesehatan mental serta fisik (Erick dan Smith, 2015). Data Riskesdas Tahun 2018 menunjukkan prevalensi gangguan muskuloskeletal yang menyebabkan terganggunya kegiatan sehari-hari di Indonesia mencapai 9,2\% dan di DKI Jakarta sebesar 10,1\%. PNS di Jakarta mengeluhkan nyeri pada punggung sebesar $8,3 \%$, anggota gerak atas $36 \%$, dan anggota gerak bawah 63,3\% (Kementerian Kesehatan RI, 2018). Diketahui pula bahwa pekerja kantor mengeluhkan gangguan muskuloskeletal pada leher $68 \%$, punggung atas $62 \%$, dan punggung bawah $60 \%$ dalam jangka waktu 1 tahun (Septiani, 2017).

Pada tahun 2020, pandemi COVID-19 di Indonesia mengakibatkan pemerintah menerapkan work from home (WFH). Hasil penelitian menunjukkan selama 12 bulan terakhir, sebanyak $86,3 \%$ pekerja mengalami nyeri muskuloskeletal dan $66,3 \%$ mulai mengalami nyeri selama WFH (Condrowati et al., 2020). Selain nyeri, $42 \%$ pekerja WFH sering terbangun di malam hari yang menyebabkan berkurangnya kualitas tidur (Llave dan Messenger, 2018).

\section{Muskuloskeletal disorder (MSDs)} adalah cedera yang mengakibatkan kelainan atau mengganggu sistem gerak manusia seperti otot, tendon, dan ligamen (Septiani, 2017). Terjadinya gangguan pada otot ini dapat mengganggu dalam melakukan pekerjaan atau aktivitas sehari-hari dikarenakan otot adalah salah satu bagian terpenting sebagai alat gerak (Tjahayuningtyas, 2019).

Hal-hal yang mengganggu kesehatan pekerja dapat dipengaruhi oleh sejumlah faktor yang berhubungan dengan pekerjaan ataupun tidak, misalnya bahaya kesehatan di lingkungan kerja, pelayanan kesehatan kerja, dan perilaku kerja (Uniti and Uniti, 2011). Faktor lain yang dapat memengaruhi kesehatan para pekerja adalah terganggunya tidur yang merupakan kebutuhan fisiologis (Agustin, 2012).

Tidur adalah proses aktif yang terdiri dari siklus tidur paradoksal serta siklus gelombang lambat (Lauralee, 2013). Hasil penelitian Harrison didapatkan, 41,9\% individu dewasa mengalami keluhan atau nyeri muskuloskeletal dengan periode tidur yang sebentar (Harrison, 2014)

Nyeri yang dialami ini akan timbul menjadi suatu gangguan muskuloskeletal yang dapat berpengaruh pada aspek-aspek tertentu dalam suatu perusahaan atau perkantoran. Masalah tersebut menyebabkan menurunnya output, tidak tercapainya deadline akibat produksi atau pelayanan yang tidak memuaskan. Selain itu, peningkatan absensi pekerja akan menambah biaya untuk melatih karyawan pengganti sehingga akan mengurangi keuntungan. Data Komite Pengawas Eropa menunjukkan 49,9\% ketidakhadiran selama tiga hari dan $60 \%$ ketidakmampuan permanen untuk bekerja disebabkan oleh penyakit musculoskeletal.

Maka dari latar belakang diatas penelitian ini adalah untuk memahami hubungan antara kualitas tidur dengan keluhan muskuloskeletal pada tenaga kependidikan dan dosen Fakultas Kedokteran UPNVJ menggunakan PSQI dan NMQ.

\section{METODE}

Penelitian ini menggunakan desain potong lintang yang dilakukan di Universitas Pembangunan Nasional Veteran Jakarta sejak bulan Desember 2020 hingga Januari 2021. Populasi dalam penelitian ini adalah seluruh tenaga kependidikan dan dosen Fakultas Kedokteran Universitas Pembangunan Nasional Veteran Jakarta. 
Sampel pada penelitian ini yang diambil menggunakan teknik purposive sampling adalah 50 tenaga kependidikan dan 81 dosen FK UPNVJ yang memenuhi kriteria inklusi yaitu seluruh staf akademik FKUPNVJ yang bersedia menjadi responden dan kriteria eksklusi yaitu sampel didiagnosis memiliki gangguan tulang, riwayat trauma/operasi tulang, dan memiliki kelainan bentuk tulang belakang (kifosis, lordosis, atau skoliosis).

Data kualitas tidur (variabel independen) dan keluhan muskuloskeletal (variabel dependen) dikumpulkan melalui kuesioner yang disebarkan secara daring. Selanjutnya dilakukan analisis univariat untuk mengidentifikasi karakteristik tiap variabel dan analisis bivariat untuk mengetahui hubungan antara kualitas tidur dengan keluhan muskuloskeletal pada staf FK UPNVJ. Uji Chi-square digunakan karena ukuran data variabel penelitian bersifat kategorik dan tidak berpasangan.

\section{HASIL}

\section{Karakteristik Responden}

Pada Tabel 1 dapat dilihat mayoritas responden adalah perempuan dengan jumlah 46 orang $(54,8 \%)$ dan berusia paling banyak $\geq 41$ tahun (50\%). Mayoritas responden memiliki masa kerja $\geq 5$ Tahun sebanyak 54 orang $(64,3 \%)$ dengan durasi jam kerja $>40$ jam per minggu sebanyak 47 orang $(56 \%)$ yang mendominasi. Berdasarkan IMT, mayoritas responden obesitas sebanyak 38 orang $(45,2 \%)$ dan keseluruhan responden memiliki tangan dominan kanan.

Tabel 1 Distribusi Karakteristik Responden

\begin{tabular}{lll}
\hline Variabel & n & \% \\
\hline Jenis Kelamin & & \\
Laki-laki & 38 & 45,2 \\
Perempuan & 46 & 54,8 \\
\hline Usia & & \\
20-25 tahun & 6 & 7,2 \\
26-30 tahun & 13 & 15,4 \\
\hline
\end{tabular}

\begin{tabular}{lll}
\hline Usia & & \\
$31-35$ tahun & 5 & 6 \\
$36-40$ tahun & 18 & 21,4 \\
$\geq 41$ tahun & 42 & 50 \\
\hline Masa Kerja & & \\
$<5$ Tahun & 30 & 35,7 \\
$\geq 5$ Tahun & 54 & 64,3 \\
\hline Durasi Kerja & & \\
(jam/minggu) & & \\
$\leq 40$ & 37 & 44 \\
$>40$ & 47 & 56 \\
\hline IMT & & \\
Gizi kurang & 1 & 1,2 \\
Gizi normal & 22 & 26,2 \\
Gizi berlebih & 23 & 27,4 \\
Obesitas & 38 & 45,2 \\
\hline Tangan Dominan & & \\
Kanan & 84 & 100 \\
Kiri & 0 & 0 \\
\hline Total & $\mathbf{8 4}$ & $\mathbf{1 0 0}$ \\
\hline
\end{tabular}

\section{Kualitas Tidur}

Pada penelitian ini, kualitas tidur didapatkan berdasarkan skor kuesioner Pittsburgh Sleep Quality Index (PSQI) yang terbagi menjadi 7 komponen, yaitu kualitas tidur subjektif, latensi tidur, durasi tidur, efisiensi tidur, gangguan tidur, penggunaan obat-obatan, dan disfungsi aktivitas di siang hari. Pada Tabel 2 mayoritas responden merasa memiliki kualitas tidur yang cukup baik sebanyak 57 orang $(67,9 \%)$, memiliki skor latensi tidur 1-2 sebanyak 37 orang (44\%) yang menunjukkan latensi tidur cukup baik, durasi tidur 6-7 jam sebanyak 38 orang $(45,2 \%)$, efisiensi tidur $\geq 85 \%$ sebanyak 68 orang (81\%), skor gangguan tidur 1-9 sebanyak 67 orang $(79,8 \%)$, kebanyakan responden tidak pernah menggunakan obat-obatan untuk membantu tidurnya sebanyak 81 orang $(96,4 \%)$, dan skor disfungsi 3-4 sebanyak 56 orang $(66,7 \%)$ menandakan responden cenderung mengantuk dan kurang antusias menghadapi aktivitas di siang hari. Berdasarkan hasil perhitungan 7 komponen tersebut, didapatkan skor akhir kualitas tidur mayoritas responden $>5$ atau kualitas tidur buruk sebanyak 79 orang (94\%). 
Tabel 2 Distribusi Responden Berdasarkan Komponen Kualitas Tidur Dalam 1 Bulan Terakhir

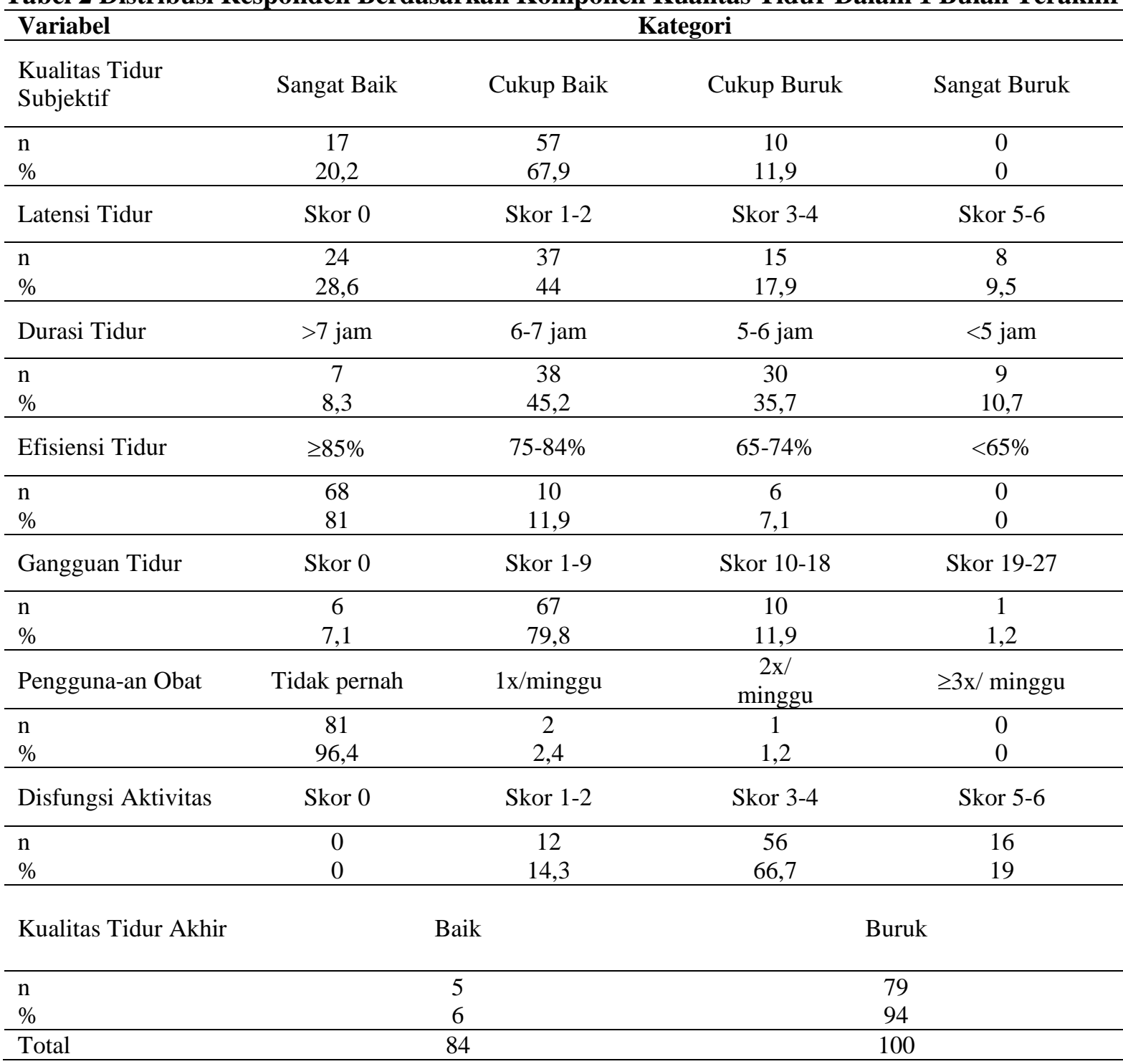

\section{Keluhan Muskuloskeletal}

Keluhan musculoskeletal dinilai dari ada tidaknya jawaban "ya" yang diisi oleh responden pada 27 pertanyaan kuesioner NMQ untuk tiap regio atau bagian tubuh. Disertai pertanyaan khusus untuk 3 regio spesifik yaitu leher, bahu, dan punggung bawah. Keseluruhan pertanyaan ini dibagi dalam 2 jangka waktu yaitu dalam 7 hari terakhir dan 12 bulan terakhir untuk melihat keluhan tersebut akut atau kronik.
Kuesioner ini juga menilai ada tidaknya gangguan aktivitas sehari-hari akibat MSDs.

Distribusi responden menurut keluhan muskuloskeletal dalam 7 hari terakhir dapat dilihat pada Tabel 3 yang menggambarkan jumlah keluhan tertinggi berada di regio spesifik yaitu di leher sebanyak 29 orang $(34,5 \%)$, bahu sebanyak 21 orang (25\%), dan punggung bawah sebanyak 24 orang $(28,6 \%)$. 
Tabel 3 Distribusi Responden Berdasarkan Keluhan Muskuloskeletal Dalam 7 Hari Terakhir

\begin{tabular}{|c|c|c|c|c|}
\hline Regio & Tidak & Ya & & \\
\hline Leher & $55(65,6 \%)$ & $29(34,5 \%)$ & & \\
\hline Bahu & $63(75 \%)$ & $21(25 \%)$ & & \\
\hline Sikut & $63(75 \%)$ & $21(25 \%)$ & & \\
\hline Punggung Atas & $71(84,5 \%)$ & $13(15,5 \%)$ & & \\
\hline Punggung Bawah & $60(71,4 \%)$ & $24(28,6 \%)$ & & \\
\hline Panggul & $74(88,1 \%)$ & $10(11,9 \%)$ & & \\
\hline Lutut & $72(85,7 \%)$ & $12(14,3 \%)$ & & \\
\hline \multirow[t]{2}{*}{ Kaki } & $74(88,1 \%)$ & $10(11,9 \%)$ & & \\
\hline & & Kanan & Kiri & Keduanya \\
\hline Pergelangan & $78(92,9 \%)$ & $4(4,8 \%)$ & $2(2,4 \%)$ & $0(0 \%)$ \\
\hline Total & 84 & 100 & & \\
\hline
\end{tabular}

Distribusi responden berdasarkan keluhan muskuoseletal dalam 12 hari terakhir dapat dilihat pada Tabel 4 bahwa mayoritas responden mengalami keluhan kronik muskuloskeletal di regio leher sebanyak 23 orang $(27,4 \%)$.

Tabel 4 Distribusi Responden Berdasarkan Keluhan Muskuloskeletal Dalam 12 Bulan Terakhir

\begin{tabular}{|c|c|c|c|c|}
\hline Regio & Tidak & $\mathbf{Y a}$ & & \\
\hline Leher & $61(72,6 \%)$ & $23(27,4 \%)$ & & \\
\hline Punggung Atas & $70(83,3 \%)$ & $14(16,7 \%)$ & & \\
\hline Punggung Bawah & $65(77,4 \%)$ & $19(22,6 \%)$ & & \\
\hline Panggul & $71(84,5 \%)$ & $13(15,5 \%)$ & & \\
\hline Lutut & $72(85,7 \%)$ & $12(14,3 \%)$ & & \\
\hline \multirow[t]{2}{*}{ Kaki } & $73(86,9 \%)$ & $11(13,1 \%)$ & & \\
\hline & & Kanan & Kiri & Keduanya \\
\hline Bahu & $75(89,3 \%)$ & $4(4,8 \%)$ & $3(3,6 \%)$ & $2(2,4 \%)$ \\
\hline Sikut & $75(89,3 \%)$ & $4(4,8 \%)$ & $3(3,6 \%)$ & $2(2,4 \%)$ \\
\hline Pergelangan & $74(88,1 \%)$ & $6(7,1 \%)$ & $4(4,8 \%)$ & $0(0 \%)$ \\
\hline Total & 84 & 100 & & \\
\hline
\end{tabular}

Distribusi responden menurut terganggunya aktivitas sehari-hari akibat keluhan muskuloskeletal dalam 12 bulan terakhir dapat dilihat pada Tabel 5. Terlihat gambaran bahwa mayoritas responden memiliki gangguan aktivitas akibat keluhan di regio punggung atas sebanyak 7 orang $(8,3 \%)$ dan lutut sebanyak 7 orang $(8,3 \%)$.

Tabel 5 Distribusi Responden Berdasarkan Terganggunya Aktivitas Sehari-hari Akibat Keluhan Muskuloskeletal Dalam 12 Bulan Terakhir

\begin{tabular}{lll}
\hline Regio & Tidak & Ya \\
\hline Leher & $78(92,9 \%)$ & $6(7,1 \%)$ \\
Bahu & $83(98,8 \%)$ & $1(1,2 \%)$ \\
Sikut & $83(98,8 \%)$ & $1(1,2 \%)$ \\
Punggung Atas & $77(91,7 \%)$ & $7(8,3 \%)$ \\
Punggung Bawah & $80(95,2 \%)$ & $4(4,8 \%)$ \\
Panggul & $78(92,9 \%)$ & $6(7,1 \%)$ \\
Lutut & $77(91,7 \%)$ & $7(8,3 \%)$ \\
\hline
\end{tabular}




\begin{tabular}{|c|c|c|c|c|}
\hline $\begin{array}{l}\text { Regio } \\
\text { Kaki }\end{array}$ & \multirow{3}{*}{$\begin{array}{l}\text { Tidak } \\
83(98,8 \%)\end{array}$} & Ya & & \\
\hline \multirow[t]{2}{*}{ Kaki } & & \multicolumn{3}{|l|}{$1(1,2 \%)$} \\
\hline & & Kanan & Kiri & Keduany: \\
\hline Pergelangan & $80(95,2 \%)$ & $3(3,6 \%)$ & $0(0 \%)$ & $1(1,2 \%)$ \\
\hline Total & 84 & 100 & & \\
\hline
\end{tabular}

Distribusi responden berdasarkan ada tidaknya keluhan muskuloskeletal menunjukkan bahwa mayoritas responden memiliki keluhan muskuloskeletal sebanyak 62 orang $(73,8 \%)$.

\section{Kualitas Tidur dan Keluhan Muskuloskeletal}

Pada penelitian ini digunakan uji Fisher sebagai alternatif uji Chi-square dan didapatkan nilai $\mathrm{p}=0,016$. Hasil ini menunjukkan terdapat hubungan yang signifikan antara kualitas tidur dengan keluhan muskuloskeletal dengan $\mathrm{OR}=$ 13,55. Hal tersebut berarti bahwa responden yang memiliki kualitas tidur buruk berisiko 13,5 kali mengalami keluhan muskuloskeletal.

Tabel 6 Hubungan Antara Tidur Dengan Keluhan Muskuloskeletal

\begin{tabular}{|c|c|c|c|c|c|c|c|}
\hline \multirow[t]{3}{*}{$\begin{array}{l}\text { Kualitas } \\
\text { Tidur }\end{array}$} & \multicolumn{4}{|c|}{$\begin{array}{c}\text { Keluhan } \\
\text { Muskuloskeletal }\end{array}$} & \multirow{2}{*}{\multicolumn{2}{|c|}{ Total }} & \multirow{3}{*}{$\begin{array}{c}\text { OR } \\
(95 \% \\
\text { CI) }\end{array}$} \\
\hline & \multicolumn{2}{|c|}{ Ya } & \multicolumn{2}{|c|}{ Tidak } & & & \\
\hline & $\mathbf{n}$ & $\%$ & $\mathrm{n}$ & $\%$ & $\mathbf{N}$ & $\%$ & \\
\hline Baik & 1 & 20 & 4 & 80 & 5 & 100 & 13,55 \\
\hline Buruk & 61 & 77,2 & 18 & 22,8 & 79 & 100 & $1,42-$ \\
\hline Total & 62 & 97,2 & 22 & 102,8 & 84 & 100 & 129,06 \\
\hline
\end{tabular}

\section{PEMBAHASAN}

\section{Kualitas Tidur}

Hasil analisis data menunjukkan sebanyak 94\% dari 84 responden memiliki kualitas tidur yang buruk. Hasil ini sejalan dengan penelitian terdahulu yang menyatakan bahwa $17 \%$ populasi pada negara berkembang mengalami gangguan tidur, dimana gangguan tidur merupakan salah satu komponen yang mepengaruhi kualitas tidur (Berhanu et al., 2018). Disebutkan juga pada jurnal investigasi epidemiologi di Inggris adanya hubungan usia dengan menurunnya efisiensi tidur dimulai pada umur 25 tahun. Responden penelitian ini mayoritas berusia lebih dari 25 tahun sehingga dapat menjadi faktor risiko responden memiliki kualitas tidur yang buruk (Gadie et al., 2017).

Latensi tidur adalah waktu yang dibutuhkan dari keadaan terbangun hingga tertidur. Menurut jurnal Sleep in Normal Aging, latensi tidur akan meningkat pada usia 20 tahun-an, konstan pada usia 30-50 tahun, dan meningkat kembali pada usia 50 tahun. Pernyataan ini sejalan dengan hasil penelitian yang menunjukkan latensi tidur mayoritas responden yang berusia antara 36 hingga lebih dari 41 tahun tergolong cukup baik (Li, Vitiello dan Gooneratne, 2019).

Durasi tidur adalah jumlah jam tidur yang didapatkan dalam tidur malam atau dalam 24 jam. Menurut organisasi Sleep foundation, durasi tidur normal untuk usia 18-64 tahun adalah 7-9 jam (Nation Sleep FBundation, 2019). Namun pada umumnya Yalus durasi tidur akan semakin menurun seiring bertambahnya usia. Pernyataan ini didukung oleh penelitian Campbell tahun 2007 yang menyatakan bahwa dari kelompok dewasa muda, dewasa, dan lansia terdapat penurunan signifikan sebesar 1-2 jam dari durasi tidur dewasa muda (Li, Vitiello and Gooneratne, 2019). CDC juga melaporkan bahwa $35,5 \%$ perempuan Amerika memiliki durasi tidur <7jam, dengan kelompok usia 35-54 tahun yang memiliki persentase terbesar untuk durasi tidur pendek (Center for Disease Control and Prevention, 2017). Penelitian lain juga menemukan bahwa beban kerja dan personal yang tinggi, menuntut dosen dan tenaga kependidikan memulai aktivitasnya di pagi hari dan menyelesaikan di malam hari (de Souza et al., 2014). Hal ini dapat menurunkan durasi tidur, yang 
tergambarkan pada penelitian ini bahwa kelompok pengajar yang mayoritas berusia 32 hingga $\geq 41$ tahun memiliki durasi tidur $>7$ jam.

Efisiensi tidur adalah rasio jumlah waktu tidur dengan jumlah waktu di kasur (Reed and Sacco, 2016). Efisiensi tidur ini pada kelompok umur anak hingga dewasa muda cenderung konstan dan tidak mengalami perubahan, tetapi ketika memasuki usia dewasa, terdapat penurunan signifikan seiring bertambahnya usia (Li, Vitiello and Gooneratne, 2019). Pernyataan ini tidak sejalan dengan hasil penelitian dimana mayoritas responden berusia $\geq 41$ tahun memiliki efisiensi tidur yang baik. Penurunan efisiensi tidur pada 6 responden pada penelitian ini termasuk kelompok usia 25-53 tahun.

Menurunnya kualitas tidur juga dapat dipengaruhi oleh stres akibat pekerjaan yang menganggu tidur lelap dan penggunaan obat-obatan yang digunakan oleh $3,6 \%$ responden untuk membantu tidurnya. Hal ini mengindikasikan kualitas tidur responden tersebut kurang baik sehingga memerlukan bantuan obat-obatan. Faktor lain yang dapat mempengaruhi adalah adanya nyeri otot yang dapat timbul pada saat tidur sehingga individu tersebut akan terbangun di tengah-tengah waktu tidurnya.

\section{Keluhan Muskuloskeletal}

Pada penelitian ini didapatkan sebanyak 73,8\% dari 84 responden mengeluhkan nyeri muskuloskeletal. Hasil ini sejalan dengan penelitian terdahulu yang menyatakan umumnya nyeri muskuloskeletal dikeluhkan oleh kelompok usia 33-55 tahun yang bekerja dalam posisi statis seperti tenaga kependidikan dengan jam kerja mayoritas 8 jam per hari di depan komputer dalam posisi duduk (Wulan et al., 2010). Pada penelitian ini tergambarkan mayoritas responden berusia 32 hingga $\geq 41$ tahun yang bekerja dalam posisi stasis dalam jangka waktu yang lama, terutama saat WFH selama 9 bulan terakhir dapat menyebabkan timbulnya keluhan muskuloskeletal.

Kerja yang repetitif dan monoton merupakan dua faktor yang dapat meningkatkan risiko terjadinya keluhan muskuloskeletal. Regio yang paling berisiko untuk terkena adalah bahu, leher, punggung, lengan, dan pergelangan tangan (Luger et al., 2017). Pada penelitian sebelumnya, disebutkan bahwa $81 \%$ pekerja kantoran mengeluhkan nyeri punggung (Quemelo, Gasparato and Vieira, 2015). Hasil ini sedikit berbeda dengan hasil penelitian yang menunjukkan bahwa mayoritas responden mengeluhkan nyeri di $(34,5 \%)$, bahu $(25 \%)$, dan punggung $(28,6 \%)$ tetapi tetap memperlihatkan gambaran keluhan muskuloskeletal di tempat kerja. Hal ini dapat diakibatkan oleh stres otot tambahan selama masa WFH dengan posisi bekerja tidak ergonomis sehingga individu akan cenderung duduk dalam kondisi membungkuk yang menimbulkan tegang otot bagian bahu dan punggung serta dengan kurangnya aktivitas fisik untuk meregangkan otot-otot tersebut.

Pada penelitian lain, disebutkan juga bahwa prevalensi keluhan muskuloskeletal dalam 12 bulan terakhir pada regio leher $(56,6 \%)$, pergelangan tangan $(46,7 \%)$, dan punggung bawah $(44,6 \%)$ berhubungan dengan kelelahan di tempat kerja (Daneshmandi et al., 2017). Hasil ini sesuai dengan data responden yang mengeluhkan nyeri muskuloskeletal dalam 12 bulan terakhir paling banyak di regio leher $(27,4 \%)$. Hal ini dapat berkaitan dengan posisi laptop yang kurang ergonomis sehingga individu akan cenderung menunduk ke arah laptop.

Faktor IMT juga berpengaruh pada munculnya keluhan muskuloskeletal ini. Hasil penelitian yang berjudul Effect of BMI on Work Related MSDs and Occupational Stress of Computer Workers In A Developed Ergonomic Setup menunjukkan 60\% kelompok usia 31-35 tahun mengeluhkan gangguan muskuloskeletal disertai $60 \%$ responden memiliki IMT yang tinggi (Sethi, Sandhu and Imbanathan, 2011). Hasil ini 
sesuai dengan data bahwa $45,2 \%$ responden mengalami obesitas dapat menjadi faktor penyebab $73,8 \%$ responden memiliki keluhan muskuloskeletal.

\section{Hubungan Kualitas Tidur Dengan Keluhan Muskuloskeletal}

Sebanyak 61 responden $(72,6 \%)$ memiliki kualitas tidur yang buruk serta keluhan muskuloskeletal. Setelah dilakukan uji Fisher, didapatkan nilai $\mathrm{p}=0,016$. Dengan demikian dapat disimpulkan ada hubungan antara variabel kualitas tidur dengan keluhan muskuloskeletal.

Hasil penelitian ini diperkuat oleh penelitian Exploring The Association Between Sleep Problems And Chronic Musculoskeletal Pain in Adolescent bahwa $41,9 \%$ dari 6968 individu dewasa mengalami keluhan muskuloskeletal dengan periode tidur yang sebentar (Harrison, Wilson and Munafò, 2014).

Diketahui pula pada penelitian yang melibatkan 243 pekerja kantoran di Iran, bahwa kurangnya kualitas tidur dapat mengakibatkan munculnya mental workload/beban kerja yang berlebihan sehingga menimbulkan keluhan muskuloskeletal (Heidarimoghadam et al., 2019).

\section{KESIMPULAN}

Berdasarkan analisis data penelitian dapat disimpulkan terdapat 54,8\% responden berjenis kelamin perempuan, $50 \%$ berusia lebih dari 41 tahun, $73,8 \%$ responden memiliki kualitas tidur yang buruk, dan $94 \%$ responden memiliki keluhan muskuloskeletal. Terdapat hubungan antara kualitas tidur dengan keluhan muskuloskeletal.

\section{UCAPAN TERIMAKASIH}

Terimakasih kepada dosen serta tenaga kependidikan FK UPNVJ yang telah bersedia untuk menjadi responden penelitian ini.

\section{DAFTAR PUSTAKA}

Agustin, D. (2012) Faktor-Faktor Yang Mempengaruhi Kualitas Tidur Pada Pekerja Shift Di PT Krakatau Tirta. Jakarta: Fakultas Ilmu Keperawatan Universitas Indonesia.

Berhanu, H. et al. (2018) 'Prevalence and Associated Factors of Sleep Quality among Adults in Jimma Town, Southwest Ethiopia: A CommunityBased Cross-Sectional Study', pp. 110.

Center for Disease Control and Prevention (2017), 'CDC - Data and Statistics Sleep and Sleep Disorders', p. 1.

Condrowati et al. (2020) 'Musculoskeletal Disorder of Workers During Work From Home on Covid-19 Pandemic: A Descriptive Study', 30(Ichd), pp. 153-160.

Daneshmandi, H. et al. (2017) 'The effect of musculoskeletal problems on fatigue and productivity of office personnel: A cross-sectional study', Journal of Preventive Medicine and Hygiene, pp. E252-E258.

de Souza, J. C. et al. (2014) 'Work schedule influence on sleep habits in elementary and high school teachers according to chronotype', Estudos de Psicologia, pp. 200-209.

Erick, P. N. and Smith, D. R. (2015) 'Musculoskeletal disorders in the teaching profession: An emerging workplace hazard with significant repercussions for developing countries', Industrial Health, pp. 385386.

Gadie, A. et al. (2017) 'How are age-related differences in sleep quality associated with health outcomes? An epidemiological investigation in a UK cohort of 2406 adults', BMJ Open.

Harrison, L., Wilson, S. and Munafò, M. R. (2014) 'Exploring the associations between sleep problems and chronic musculoskeletal pain in adolescents: A prospective cohort study', Pain Research and Management, pp. e139- 
e145.

Harrison, L., Wilson, S. and Munafò, M. R. (2014), 'Exploring the associations between sleep problems and chronic musculoskeletal pain in adolescents: A prospective cohort study', Pain Research and Management, pp. e139e145.

Heidarimoghadam, R. et al. (2019), 'Does mental workload can lead to musculoskeletal disorders in healthcare office workers? Suggest and investigate a path', Cogent Psychology. Cogent, p6(1).

Kementrian Kesehatan RI (2018) 'Laporan Nasional RISKESDAS 2018', Lembaga Penerbit BALITBANGKES.

Lauralee, S. (2013) From cells to systems8th edn, Cengage Learning. Belmont, CA: Brokks/Cole.

Li, J., Vitiello, M. and Gooneratne, N. (2019), 'Sleep in Normal Aging'.

Luger, T. et al. (2017) 'Work-break schedules for preventing musculoskeletal disorders in workers', Cochrane Database of Systematic Reviews.

Nation Sleep Foundation (2019), 'National Sleep Foundation Recommends New Sleep Times', National Sleep Foundation, pp. 1-4.

Quemelo, P. R. V., Gasparato, F. D. S. and Vieira, E. R. (2015) 'Prevalence, risks and severity of musculoskeletal disorder symptoms among administrative employees of a Brazilian company', pp. 533-540.
Reed, D. L. and Sacco, W. P. (2016) 'Measuring sleep efficiency: what should the denominator be?', Journal of Clinical Sleep Medicine, pp. 263266.

Septiani, A. (2017) Faktor-faktor Yang Berhubungan Dengan Keluhan Musculoskeletal Disorders (MSDs) Pada Pekerja Bagian Meat Preparation PT. Bumi Sarimas Indonesia Tahun 2017. Jakarta: Fakultas Kedokteran dan Ilmu Kesehatan UIN Syarif Hidayatullah.

Sethi, J., Sandhu, J. S. and Imbanathan, V. (2011) 'Effect of Body Mass Index on work related musculoskeletal discomfort and occupational stress of computer workers in a developed ergonomic setup', Sports Medicine, Arthroscopy, Rehabilitation, Therapy \& Technology.

Tarwaka (2013) Industrial Ergonomics, Basics of Ergonomic Knowledge and Applications at Workplace. Surakarta: Harapan Press.

Uniti, S., \& Uniti, N. S. (2011) Hubungan Posisi Meja Kerja dan Keluhan Musculoskeletal Disorders (Msds) Yang Dirasakan Oleh Para Pekerja Back Office PT. Nitra Sanata Dharma. Esa Unggul.

Wulan, D. et al. (2010) 'Nyeri Punggung pada Operator Komputer Akibat Posisi dan Lama Duduk Computer Operator', $M K B$ Vol. 42, No. 3, Pages. 123-127. 